УДК 81'374:303.4

DOI https://doi.org/10.26661/2414-1135-2021-84-33

\title{
КАТЕГОРІАЛЬНЕ ЗАБЕЗПЕЧЕННЯ НАУКОВИХ ДОСЛІДЖЕНЬ В ЕКОНОМІЧНИХ НАУКАХ ТА ДЕРЖАВНОМУ УПРАВЛІННІ
}

\author{
Сивак О. Б. \\ кандидат економічних наук, дочент, \\ дочент кафедри теоретичної та прикладної лінгвістики \\ Державний університет «Житомирська політехніка» \\ вул. Чуднівська, 103, Житомир, Україна \\ orcid.org/0000-0002-2799-3685 \\ olena_syvak@ukr.net \\ Орлова К. Є. \\ кандидат економічних наук, дочент, \\ доцент кафедри менеджменту і підприємництва \\ Державний університет «Житомирська політехніка» \\ вул. Чуднівська, 103, Житомир, Украӥна \\ orcid.org/0000-0002-9985-0210. \\ orlova_ekaterina@ukr.net
}

Ксендзук В. В.

доктор наук з державного управління, кандидат економічних наук, доцент, доиент кафедри економічної безпеки, публічного управління та адміністрування

Державний університет «Житомирська політехніка»

вул. Чуднівська, 103, Житомир, Україна

orcid.org/0000-0001-7670-7350

walentyna_ksiedzuk@ukr.net

Ключові слова: система забезпечення, понятійний апарат, електронні багатомовні академічні словники, терміносистема, інформаційне забезпечення.
У статті визначено роль системи підтримки проведення наукових досліджень у сфері економіки та державного управління. У дослідженні обгрунтовано те, що наукові дослідження визначають особливості соціально-економічних характеристик країни, перспективи ії розвитку та рівень життя. Питання, пов'язані з інтенсифікацією наукових досліджень в економіці та державному управлінні, є особливо актуальними, оскільки ці сфери досліджень, поряд із технічним напрямом, визначають ключові основи суспільства. Уважаємо, що однією 3 найважливіших передумов активізації та належної організації наукових досліджень є система їх підтримки. Опорна система як сукупність компонентів, що визначають можливості наукової роботи, є складним явищем, що включає єдність відповідних елементів.

Структура системи забезпечення визначається так: кадрове забезпечення, методичне забезпечення, технічне забезпечення й інформаційне забезпечення. Інформаційна підтримка, а також кадрова підтримка $є$ двома найважливішими елементами наукового процесу. Ми вважаємо, що одним із ключових елементів інформаційного забезпечення наукового дослідження є підтримка категорій як відповідної терміносистеми, що використовується в певній галузі дослідження. Підтримка категорій істотно впливає на особливості організації наукових досліджень, їхньої раціоналізації, процес інтеграції вітчизняних наукових досягнень 
у світовий інформаційний простір. За результатами вивчення прикладів 3 економіки та державного управління виявлено проблеми в узгодженні та співвіднесенні термінології вітчизняної та зарубіжної науки. Відмінності між конотаціями термінів як в економіці, так і в державному управлінні впливають на якість і обсяг результатів досліджень українських учених. Подолання цієї проблеми можливе, на нашу думку, шляхом формування електронних багатомовних академічних словників у відповідних сферах, що сприятиме гармонізації категоріального апарату дослідження та надасть більші можливості для інтеграції вітчизняних науковців у світовий науковий простір.

Авторами визначено роль системи забезпечення для проведення наукових досліджень у сфері економічних наук та державного управління. 3'ясовано, що категоріальне забезпечення суттєво впливає на особливості організації наукових досліджень, їх раціоналізацію та процес інтеграції вітчизняного наукового доробку у світовий інформаційний простір. Ідентифіковано роль електронних багатомовних академічних словників у процесі формування категоріального забезпечення наукових досліджень.

\title{
CATEGORY SUPPORT OF SCIENTIFIC RESEARCH IN ECONOMIC SCIENCES AND PUBLIC ADMINISTRATION
}

\author{
Syvak O. B. \\ Candidate of Economic Sciences, Associate Professor, \\ Associate Professor at the Department of Theoretical and Applied Linguistics \\ Zhytomyr Polytechnic State University \\ Chudnivska str., 103, Zhytomyr, Ukraine \\ orcid.org/0000-0002-2799-3685 \\ olena_syvak@ukr.net \\ Orlova K. Ye. \\ Candidate of Economic Sciences, Associate Professor, \\ Associate Professor at the Department of Management and Entrepreneurship \\ Zhytomyr Polytechnic State University \\ Chudnivska str., 103, Zhytomyr, Ukraine \\ orcid.org/0000-0002-9985-0210. \\ orlova_ekaterina@ukr.net
}

\section{Ksendzuk V. V.}

Doctor of Science in Public Management, Candidate of Economic Sciences, Associate Professor, Associate Professor at the Department of Economic Security, Public Management and Administration

Zhytomyr Polytechnic State University

Chudnivska str., 103, Zhytomyr, Ukraine

orcid.org/0000-0001-7670-7350

walentyna_ksiedzuk@ukr.net

Key words: support system, conceptual apparatus, electronic multilingual academic dictionaries, terminology system, information support.
The article defines the role of the support system for conducting scientific research in the sphere of Economics and Public Administration. The study substantiates the fact that scientific research determines the features of socio-economic characteristics of the country and prospects for its development, living standards. Issues related to the intensification of scientific research in Economics and Public Administration are especially relevant because these spheres of research, alongside the technical direction, determine the key foundations of society. We believe that one of the most important prerequisites for the activation and proper organization of scientific research is the system of their support. The support system as 
a set of components that determine the possibilities of scientific work is a complex phenomenon that includes the unity of the relevant elements.

The structure of the support system is defined as the following: staff support, methodological support, technical support, and informational support. Informational support as well as staff support are two most important elements of the scientific process. We believe that one of the key elements of informational support of scientific research is the category support as an appropriate terminology system used in a particular area of research. The category support has a significant impact on the peculiarities of the organization of scientific research, its rationalization, and the process of integration of domestic scientific achievements into the world information space. According to the study of examples from Economics and Public Administration, problems in agreeing and correlating of the terminology of domestic and foreign science were detected. The differences between the connotation of terms in both Economics and Public Administration spheres affect the quality and scope of research results of Ukrainian scientists. Overcoming this problem is possible, in our opinion, through the formation of electronic multilingual academic dictionaries in the appropriate spheres, which will help to harmonize the categorical apparatus of research and provide greater opportunities for integration of domestic scientists into the world scientific space.

The authors define the role of the support system for conducting research in the field of Economics and Public Administration. It was found that the categorical support has a significant impact on the peculiarities of the organization of scientific research, their rationalization and the process of integration of domestic scientific achievements into the world information space. The role of electronic multilingual academic dictionaries in the process of formation of categorical support of scientific researches is identified.

Постановка проблеми. Наукові дослідження $\epsilon$ безумовним та надважливим компонентом розвитку суспільства загалом і окремих галузей знань зокрема, адже формують підгрунтя для вдосконалення та видозміни суспільно-економічних відносин, особливостей організації виробництва економічних благ, еволюції країни загалом. Перспективи розвитку суспільства значною мірою визначаються ступенем активності наукової діяльності та швидкістю впровадження передових досягнень науки у практичну діяльність. Отже, від раціональності й ефективності організації процесів наукових досліджень значною мірою залежать суспільно-економічний лад у країні, рівень прогресу та життя населення. Особливо важливою постає проблема ефективності наукових досліджень у сфері економічних наук та державного управління, адже, з одного боку, економічні відносини пронизують усі сфери суспільного життя, з іншого боку, державне управління визначає перспективи розвитку певної країни в цілому. Актуальність досліджень у сфері публічного управління можна пояснити збільшенням видатків державного бюджету на загальнодержавні функції. Адже, як зазначає [15], у XIX ст. роль держави обмежувалася майже суто функцією нічного сторожа, описаною Адамом Смітом, а державні витрати в більшості країн світу не перевищували 10\% ВВП. Натомість сьогодні для порівняння в Україні загальнодержавні видатки становили у 2020 р. приблизно 15\% державного бюджету [5]. Отже, формування системи забезпечення наукових досліджень є важливим завданням 3 огляду на роль науки в житті суспільства. Категоріальне забезпечення ж, у свою чергу, визначає можливість інтеграції вітчизняного наукового доробку у світовий інформаційний простір та здатність використовувати передовий досвід інших країн, адаптувати його до реалій України.

Варто відзначити, що увага вчених до формування системи забезпечення наукових досліджень здебільшого концентрована на інформаційному ii компоненті. Зокрема, особливості формування інформаційного забезпечення наукових досліджень розглянуто в роботах таких науковців, як: I. Адамова, Н. Артамонова, Т. Власова, С. Горбатюк, М. Сукач, Л. Філіпова й інші. Формуванню терміносистем у сфері економічних наук присвячено роботи таких дослідників, як: В. Іщенко, М. Кузів, Т. Кравченко, Н. Пілецька, В. Товстенко, Г. Чорновол та інші; у сфері державного управління - Т. Ілюк, С. Кравченко, Н. Коцюба, Л. Штика.

Зазначаємо вагомий науковий внесок перелічених та інших дослідників, проте маємо зауважити, що питання, пов'язані 3 діалектикою формування категоріального забезпечення наукових досліджень як передумовою їхньої ефективності та раціональності, залишаються маловисвітленими, що і зумовлює актуальність подальших наукових пошуків у визначеній царині.

Мета і завдання статті. Метою дослідження $\epsilon$ визначення ключових засад формування категоріального забезпечення наукових досліджень в економічних науках та державному управлінні як передумови вдосконалення наукового процесу.

Виклад основного матеріалу дослідження. Розвиток суспільства в будь-якій сфері, зокрема й у соціально-економічній, значною мірою залежить від наукових досягнень, а також швидкості їх упровадження у практичну сферу діяльності людини. Отже, рівень організації й ефективності наукових досліджень визначає особливості суспільно-економічного розвитку країни та його 
перспективи, рівень життя населення. Особливо актуальними постають питання, пов'язані з активізацією наукових пошуків в економічних науках та у сфері державного управління, адже саме ці напрями наукових досліджень, сукупно 3 технічним напрямом, визначають ключові підвалини розвитку суспільства. Уважаємо, що однією з найбільш вагомих передумов активізації та належної організації наукових досліджень $є$ система їх забезпечення.

Варто зауважити, що в науковому доробку вітчизняних учених система забезпечення наукових досліджень представлена в основному через інформаційну складову частину. Також розглядається методичний інструментарій проведення наукових досліджень. Водночас, на нашу думку, система забезпечення як сукупність компонентів, що визначають можливості проведення наукової роботи, $є$ комплексним явищем, яке містить у собі єдність відповідних елементів (рис. 1).

На рис. 1 бачимо, що основними компонентами системи забезпечення наукових досліджень в економічних науках та державному управлінні $\epsilon$ такі:

- кадрове забезпечення - включає науковців різних рівнів та інституцій, а також організації, що здійснюють наукову діяльність, як суб'єктів проведення наукових досліджень. Характеризується інтелектуальним потенціалом, кваліфікаційними та професійними характеристиками відповідних суб'єктів;

- методичне забезпечення - визначається сукупністю загальнонаукових (аналіз, синтез, узагальнення, формалізація, індукція, дедукція тощо) та специфічних (функціонально-вартісний аналіз, конкурентний аналіз, PEST-аналіз, SWOT-аналіз тощо) методів, що $\epsilon$ доцільними для використання 3 огляду на тематику та мету наукового дослідження;
- технічне забезпечення - містить сукупність технічних засобів та засобів програмного забезпечення, які можуть бути використані у процесі наукових досліджень;

- інформаційне забезпечення - система даних, а також процесів їх накопичення, обробки і зберігання, що задовольняє інформаційні потреби суб'єктів наукових досліджень.

Уважаємо, що інформаційне забезпечення, поряд із кадровим, $є$ визначальними компонентами процесу наукових досліджень, тому вважаємо за доцільне більш детально розглянути зазначені елементи.

У наукових працях дослідників інформаційне забезпечення розглядається як «сукупність інформаційних процесів 3 підготовки і надання наукової інформації користувачу для вирішення наукових завдань відповідно до етапів їхнього виконання» $[10$, c. 25$]$. У роботах $[1 ; 3]$ визначено, що основу інформаційного забезпечення формують власне інформація як сукупність даних та науково-технічна інформація як сукупність даних, отриманих у результаті пізнання.

Особливості формування інформаційного забезпечення регламентуються і на законодавчому рівні. Так, Законом України «Про інформацію» [7] визначено поняття інформації, іiі види, права й обов' язки суб'єктів інформаційних відносин. Безпосередньо інформаційне забезпечення наукових досліджень урегульовано Законом України «Про науково-технічну інформацію», яким установлено правовий режим та систему науково-технічної інформації [8].

Уважаємо, що одним із ключових елементів інформаційного забезпечення наукових досліджень, у свою чергу, виступає категоріальне забезпечення як відповідна терміносистема, що вживається за певним напрямом досліджень. Визначення категоріального апарату, яким

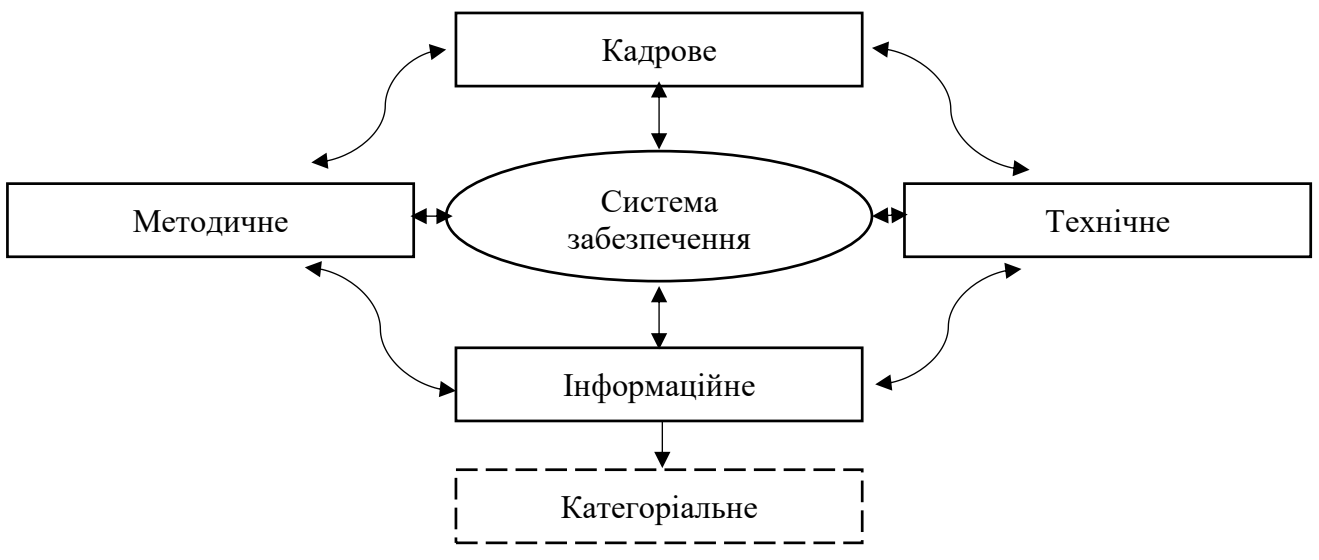

Рис. 1. Система забезпечення наукових досліджень в економічних науках та державному управління

Джерело: розроблено авторами 
послуговується та чи інша сфера досліджень, формує базис для забезпечення точності та доступності наукових доробків, інтеграції внеску окремих учених у загальний розвиток науки за відповідним напрямом. Саме визначення ключових понять, розуміння їх сутності та змісту слугує важливою передумовою для адекватної ідентифікації об’єкта досліджень, забезпечення цільового їх спрямування та якісного наповнення.

В умовах високого рівня цифровізації суспільно-економічних відносин обмін інформацією, зокрема й науково-технічною, набуває глобального та міжнародного характеру. Окремим та вкрай важливим компонентом інформаційного забезпечення виступають наукові доробки вчених 3 інших міст та країн, що надає можливість розширити аналітичну базу, адаптувати досвід інших науковців із метою оптимізації часу та зусиль на проведення наукових досліджень. Електронні ресурси натепер є чи не найважливішим джерелом інформації для здійснення досліджень у сфері економічних наук та державного управління $[1 ; 3]$. Водночас використання закордонних досягнень науки вимагає від дослідників знання іноземної мови, найчастіше англійської. I, якщо розуміння змісту наукових публікацій закордонних учених можна хоча б частково забезпечити використанням технічних засобів перекладу (яскравий приклад - Google translate), то знання саме фахової термінології є критичним із погляду пошуку релевантних публікацій, зокрема за ключовими словами, забезпечення єдності термінологічного апарату в дослідженнях, ідентифікації вчених за науковими інтересами.

Маємо зауважити, що натепер наявна вагома проблема розбіжності тлумачень ключових категорій як у сфері економічних наук, так і в галузі державного управління у вітчизняній та закордонній науковій діяльності.

3 огляду на зростання зацікавленості науковців у сфері державного управління, актуальності набуває питання трактування понять, їх характеристики в різних іноземних мовах. Відмінності, що виникають в категоріальному забезпеченні наукових досліджень, спричиняють неузгодженості та складність у розумінні базових термінів, які вживають науковці різних країн. Так, наприклад, термін "public administration" (is the implementation of government policy and also an academic discipline that studies this implementation and prepares civil employees for working in the public service) перекладається як «державне управління» - вид діяльності держави, здійснення управлінського організуючого впливу шляхом використання повноважень виконавчої влади через організацію дотримання законів, здійснення управлінських функцій із метою комплексного соціально-еко- номічного та культурного розвитку держави, іiі окремих територій, а також забезпечення реалізації державної політики у відповідних сферах суспільного життя, створення умов для реалізації громадянами їхніх прав і свобод [2].

Також термін "public management" часто вживається в публікаціях українських науковців, де тлумачиться як «публічне управління» або «державне управління». Науковці намагаються пояснити різницю між цими поняттями (державне і публічне управління, адміністрування), але єдиного підходу нині немає. Це спричиняє колізії у трактуванні понятійно-категоріального забезпечення сфери державного управління, вимагає закріплення цих термінів на законодавчому рівні.

В англійській науковій літературі наприінці XX ст. почав усе частіше вживатися такий термін, як "new public governance", що дослівно перекладається як «нове публічне управління». Однак в Україні тоді ж з'явилося поняття «ублічне управління й адміністрування», яке пояснює процес державного управління 3 участю суспільства 3 метою створення суспільного блага, підвищення добробуту і задоволення потреб населення всіх соціальних рівнів.

"Governance" трактується як "comprises all of the processes of governing - whether undertaken by the government of a state, by a market or by a network - over a social system (family, tribe, formal or informal organization, a territory or across territories) and whether through the laws, norms, power or language of an organized society" [11].

Тобто можемо зробити висновок, що такі терміни, як "management", “administration" i "governance”, перекладаються українською мовою як «управління» й ототожнюються. Отже, відбувається розмивання сутності понять, що спричиняє невідповідності в результатах наукових досліджень, що здійснюються українськомовними й англомовними вченими.

Схожі колізіі виникають у сфері функціонування економічної термінології. Наприклад, характерне для вітчизняної економічної науки поняття «товарна політика», що тлумачиться як «комплекс дій підприємства, що направлений на формування й управління конкурентоспроможним асортиментом товарів, за умов ефективного використання наявних можливостей із метою задоволення потреб споживачів і отримання компанією прибутку» [4, с. 152], дослівно перекладається англійською мовою як "product policy". Водночас уживання такого терміна не є властивим для англомовних першоджерел. Натомість поширене поняття "product strategy", яке розглядається як "decisions about product mix and lines, brands, packaging and labeling, and warranties" $[13$, p. А6] (у перекладі - рішення щзодо товарного 
асортименту та товарних ліній, брендів, пакування, маркування та гарантій). Тобто за змістом зазначені поняття $є$ зіставними та майже тотожними, проте розбіжності в ідентифікації понять можуть зумовлювати невідповідність у результатах наукових досліджень.

Іншим прикладом неузгодженості вітчизняного та закордонного понятійного апарату є термін «реклама», який може вживатися в подвійному контексті:

1) «реклама - це інформація про особу чи товар, розповсюджена в будь-якій формі та в будь-який спосіб і призначена сформувати або підтримати обізнаність споживачів реклами та їхній інтерес щодо таких особи чи товару» [9], тобто реклама як повідомлення якогось вигляду;

2) «реклама - це діяльність, спрямована на просування продукції або послуг фізичної чи юридичної особи» [6, с. 174], тобто реклама як діяльність щодо формування відповідних інформаційних повідомлень.

Водночас в англомовному категоріальному апараті такі тлумачення різняться: першій конотації відповідає термін "advertisement" ("the actual promotional messages are called advertisements, or ads for short" [12]); другій - "advertising" ("advertising is a paid form of non-personal presentation and communication about an organization and/or its goods and services, by an identified sponsor, that is transmitted to a target audience through a mass medium" [14, p. 7]). Зрозуміло, що і реклама як повідомлення, і реклама як діяльність належать до тієї самої предметної сфери досліджень, проте відмінності змістового характеру можуть спричиняти непорозуміння під час вивчення англомовних джерел та / або презентації доробків вітчизняних учених у міжнародній науковій спільності.

Отже, якщо аналізувати відмінності, що виникають у трактуванні понять у сфері досліджень в економічних науках та державному управлінні, можна зазначити, що спостерігаються неузгодженість та відсутність єдиних підходів до сутності термінів. Це впливає на якість і сферу охоплення результатів досліджень українських науковців. Тому створення термінологічних багатомовних словників має стати одним з етапів, що сприятиме узгодженості наукових досліджень та дозволятиме українським науковцям розширити сферу своїх наукових інтересів.

Уважаємо, що саме формування електронних багатомовних академічних словників галузевого спрямування може стати найбільш ефективним інструментом вирішення проблеми, пов'язаної 3 необхідністю узгодження термінологічного апарату наукових економічних досліджень. Електронні багатомовні словники виступатимуть тим «містком», який уможливить порозуміння між науковцями різних країн та дозволить уніфікувати наукову термінологію з погляду забезпечення якості, раціональності та повноти наукових досліджень у сферах економічних наук і державного управління.

Висновки та перспективи подальших розробок. Наукові дослідження загалом і у сфері економіки та державного управління зокрема виступають вагомим важелем впливу на розвиток суспільно-економічних відносин у будь-якій країні, джерелом прогресу й еволюційних змін. Отже, раціональність i ефективність наукових досліджень, які визначаються, серед іншого, якістю інформаційного забезпечення, $\epsilon$ важливим i актуальним питанням. Невід'ємним компонентом інформаційного забезпечення $\epsilon$ категоріальна складова частина, що визначає особливості формування термінологічного апарату наукових досліджень. Водночас відмінності у визначенні ключових понять у вітчизняній та закордонній науці зумовлюють різність конотацій термінів, складність у розумінні та неузгодженість наукових досліджень. Подолання такої проблеми можливе, на нашу думку, за допомогою формування електронних багатомовних академічних словників галузевого спрямування, які сприятимуть узгодженню категоріального апарату наукових досліджень та нададуть ширші можливості для інтеграції вітчизняних учених у світовий науковий простір. Перспективи подальших досліджень полягають у з'ясуванні змістового наповнення таких словників з погляду якнайповнішого задоволення інформаційних потреб суб'єктів наукових досліджень.

\section{ЛІТЕРАТУРА}

1. Адамова I., Власова Т. Проблеми інформаційного забезпечення наукових досліджень. Bicник Чернівецького торговельно-економічного інституту. Серія «Економічні науки». 2016. Вип. 3-4. С. 316-323.

2. Висоцький О., Висоцька О., Шаров Ю. Основи державного управління. Дніпропетровськ : НМетАУ, 2008. Ч. I. 52 с.

3. Горбатюк С. Інформаційне забезпечення наукового дослідження: інституційно-правові аспекти. Вісник Національної академії державного управління при Президентові України. 2014. № 4. С. 130-138.

4. Кузьминчук Н., Куценко Т., Терованесова О. Теоретичні підходи до розуміння сутності маркетингової товарної політики підприємства. Вісник економіки транспорту $і$ промисловості. 2019. № 66. С. 149-158.

5. Видатки держбюджету України 2014-2020 pp./ Міністерство фінансів України. URL: https:// index.minfin.com.ua/ua/finance/budget/gov/ expense/2014 (дата звернення: 28.11.2020). 
6. Орлова К. Управління бізнесом : підручник. Житомир : Державний університет «Житомирська політехніка», 2019. 319 c. URL: http:// eztuir.ztu.edu.ua/handle/123456789/7528;jses sionid=1FF1CEC3D0581C07371D0A7D06A C8F13 (дата звернення: 27.11.2020).

7. Про інформацію : Закон України № 2657-XII від 02.10.1992 p. URL: https://zakon.rada.gov.ua/ laws/show/2657-12\#Text (дата звернення: 29.11.2020).

8. Пронауково-технічнуінформацію:Закон України № 3322-XII від 25.06.1993 p. URL: https:// zakon.rada.gov.ua/laws/show/3322-12\#Text (дата звернення: 29.11.2020).

9. Про рекламу : Закон України № 270/96-ВР від 03.07.1996 p. URL: https://zakon2.rada.gov.ua/ laws/show/270/96-вр (дата звернення: 29.11.2020).

10. Філіпова Л., Артамонова Н. Інформаційне забезпечення наукових досліджень: тенденції розвитку (на прикладі медичної науки). Bicник Книжкової палати. 2009. № 11. С. 24-31.

11. Bevir M. Governance: A very short introduction. Oxford, UK : Oxford University Press, 2012. $152 \mathrm{p}$.

12. Advertising. Business Encyclopedia / Shopify. URL: https://www.shopify.in/encyclopedia/ advertising (дата звернення: 29.11.2020).

13. Kotler P., Keller K. Marketing management. $14^{\text {th }}$ ed. New Jersey : Prentice Hall, 2012. 812 p.

14. Lewis B.R. Advertising. The Blackwell Encyclopedia of Management. Marketing. Blackwell Publishing, 2005. $415 \mathrm{p}$.

15. Tanzi V. Gospodarcza rola Państwa w XXI wieku. Seria "Materiały i Studia". Z. 204. Warszawa : Narodowy Bank Polski, 2006. 21 s.

\section{REFERENCES}

1. Adamova, I.Z., Vlasova T.R. (2016). Problemy informatsiinoho zabezpechennia naukovykh doslidzhen [Problems of information support of scientific research]. Bulletin of the Chernivtsi Trade and Economic Institute, vol. 3-4, pp. 316-323.

2. Vysotskyi O.Yu., Vysotska O.Ye., Sharov Yu.P. (2008). Osnovy derzhavnoho upravlinnia. [Fundamentals of public administration]. Part I. Dnipropetrovsk [In Ukrainian].

3. Horbatiuk S.Ye. (2014). Informatsiine zabezpechennia naukovoho doslidzhennia: instytutsiino-pravovi aspekty [Information support of scientific research: institutional and legal aspects]. Bulletin of the National Academy of Public Administration, № 4, pp. 130-138.

4. Kuzmynchuk N.V., Kutsenko T.M., Terovanesova O.Yu. (2019). Teoretychni pidkhody do rozuminnia sutnosti marketynhovoi tovarnoi polityky pidpryiemstva [Theoretical approaches to understanding the essence of marketing product policy of the enterprise]. Bulletin of Transport Economics and Industry, № 66, pp. 149-158.

5. Ministerstvo finansiv Ukrainy. Vydatky derzhbiudzhetu Ukrainy 2014-2020 rr. [Ministry of Finance of Ukraine. Expenditures of the state budget of Ukraine 2014-2020]. Retrieved from: https://index.minfin.com.ua/ua/finance/budget/ gov/expense/2014 (accessed 28 November 2020).

6. Orlova K.Ye. (2019). Upravlinnia biznesom : pidruchnyk [Business management : a textbook]. Zhytomyr : Zhytomyr Polytechnic State University. Retrieved from: http://eztuir.ztu.edu.ua/ handle/123456789/7528; jsessionid=1FF1CEC3D0581C07371D0A7D06AC8F13 (accessed 27 November 2020).

7. Pro informatsiiu : Zakon Ukrainy [Law of Ukraine "On information" № 2657-XII of 2 October 1992]. Retrieved from: https:// zakon.rada.gov.ua/laws/show/2657-12\#Text (accessed 29 November 2020).

8. Pro naukovo-tekhnichnu informatsiiu : Zakon Ukrainy [Law of Ukraine "On scientific and technical information” № 3322-XII of 25 June 1993]. Retrieved from: https://zakon.rada.gov.ua/ laws/show/3322-12\#Text (accessed 29 November 2020 p.).

9. Pro reklamu : Zakon Ukrainy [Law of Ukraine “On advertising” № 270/96-VR of 3 July 1996]. Retrieved from: https://zakon2.rada.gov.ua/laws/ show/270/96-вp (accessed 29 November 2020).

10. Filipova L., Artamonova N. (2009). Informatsiine zabezpechennia naukovykh doslidzhen: tendentsii rozvytku (na prykladi medychnoi nauky) [Information support of scientific research: development trends (on the example of medical science)]. Bulletin of the Book Chamber. № 11, pp. 24-31.

11. Bevir M. (2012). Governance: A very short introduction. Oxford, UK : Oxford University Press [In English].

12. Advertising. Business Encyclopedia / Shopify. Retrieved from: https://www.shopify.in/encyclopedia/advertising (accessed 29 November 2020).

13. Kotler P., Keller K.L. (2012). Marketing management. $14^{\text {th }}$ ed. New Jersey : Prentice Hall. [In English].

14. Lewis B.R. (2005). Advertising. The Blackwell Encyclopedia of Management. Marketing. Blackwell Publishing [In English].

15. Tanzi V. (2006). Gospodarcza rola Państwa w XXI wieku, seria "Materiały i Studia", z. 204, Narodowy Bank Polski, Warszawa. 21 p. [In Polish]. 